\title{
Penerapan Diversi Dalam Sistem Peradilan Pidana Anak
}

\author{
Wahab Aznul Hidaya \\ Fakultas Hukum, Universitas Muhammadiyah Sorong \\ Email : Wahabaznulhidaya@gmail.com
}

\begin{abstract}
Abstrak
Anak sebagai pelaku tindak pidana dalam Undang-Undang 35 Tahun 2014 tentang Perlindungan Anak dan Undang-Undang No. 11 Tahun 2012 tentang Sistem Peradilan Pidana Anak (SPPA) perubahan atas Undang-Undang No. 3 Tahun 1997 tentang Pengadilan Anak disebut anak yang berkonflik dengan hukum yang selanjutnya disebut Anak adalah anak yang telah berumur 12 (dua belas) tahun, tetapi belum berumur 18 (delapan belas) tahun yang diduga melakukan tindak pidana.

Dengan adanya ketentuan-ketentuan mengenai anak sebagai pelaku tindak pidana, maka dalam UndangUndang No. 11 Tahun 2012 tentang Sistem Peradilan Pidana Anak dikenal adanya upaya Diversi. Diversi merupakan pengalihan penyelesaian perkara anak dari proses peradilan pidana ke proses diluar peradilan pidana. Upaya diversi wajib dilakukan di tingkat Penyidikan, Penuntutan, dan Pemeriksaan perkara anak di Pengadilan Negeri. Pelaksanaan diversi ditiap tingkat pemeriksaan masih terkendala oleh karena konsep diversi merupakan konsep yang baru di Indonesia dan ditiap tingkat pemeriksaan tersebut belum memiliki ketentuan, tindakan apa yang tepat dalam pelaksanaan upaya diversi tersebut terhadap anak sebagai pelaku tindak pidana.
\end{abstract}

Kata Kunci : Diversi, Sistem Peradilan Pidana Anak

\section{PENDAHULUAN}

Semakin pesatnya arus Globalisasi yang diikuti oleh perkembangan disegala bidang menimbulkan dampak positif dan dampak negatif. Dampak positif yang ditimbulkan antara lain semakin banyaknya hal yang dapat kita ketahui dan peroleh secara mudah. Dampak negatif yang ditimbulkan antara lain semakin besarnya keinginan atau dorongan seseorang untuk menyesuaikan diri atas arus Globalisasi tersebut dan apabila terjadi kesenjangan akantimbul potensi untuk melakukan perbuatan-perbuatan atau tindakan melawan hukum karena sarana dan prasarana yang memadai atas pesatnya arus Globalisasi tersebut.

Gejala yang terjadi menjadi pokok permasalahan. Misalnya, peningkatan kejahatan yang terjadi dalam berbagai bentuk menuntut adanya kerja keras dalam membangun pemikiranpemikiran baru mengenai kebijakan hukum sesuai dengan modus operandi yang dilakukan oleh pelaku kejahatan. Kebijakan hukum bertujuan untuk menjadikan hukum sebagai aturan yang memberikan perlindungan atas hak-hak warga negara dan menjamin kehidupan generasi di masa mendatang. Sebab itu, sistem hukum tiap negara dalam praktiknya terus mengalami modernisasi (menuju kearah yang lebih sesuai atas perkembangan masyarakat). Contohnya negara Republik 
Indonesia menuntut adanya perubahan dibidang hukum untuk mereformasi hukum yang ada saat ini.

Jumlah kejahatan yang terjadi di Indonesia relatif tinggi sehingga memerlukan tindakan penanggulangan yang serius dan efektif. Menurut data statistik lima tahun (1999-2003) jumlah kejahatan di Indonesia berjumlah 945.491 kasus, yang diselesaikan oleh aparat kepolisian berjumlah 513.567 kasus. Sehingga persentase tingkat keberhasilan penyelesaian kasus sebesar $54,31 \%$. Hal ini mengisyaratkan agar Polisi meningkatkan kinerjanya untuk menumbuhkan kepercayaan masyarakat pada hukum.

Kejahatan yang terjadi di Indonesia sangatlah beragam. Tingginya jumlah kejahatan di Indonesia menurut data statistik tahun 1999-2003 memunculkan berbagai pertanyaan. Mengapa terjadi peningkatan jumlah kejahatan di Indonesia, faktor apakah yang menyebabkannya dan bagaimana cara menanggulanginya. Pertanyaan tersebut memunculkan berbagai analisis dalam upaya menemukan bentuk penyelesaian tindak pidana yang sesuai dengan kultur budaya masyarakat Indonesia.

Peningkatan jumlah kejahatan yang dilakukan oleh anggota masyarakat setiap negara dipandang para ahli sebagai hal yang alami. Beberapa Sarjana berpendapat bahwa : "Setiap orang mempunyai peluang melakukan perbuatan menyimpang, karena kejahatan merupakan gejala yang menyangkut setiap orang."

Lebih lanjut Soerjono Soekanto mengatakan bahwa : "Manusia memiliki hasrat untuk hidup secara teratur, serasi, selaras dengan masyarakat dan hukum yang berlaku, akan tetapi karena alasan tertentu menyebabkan seseorang melanggar hukum yang berlaku. Pelanggaran tersebut terjadi karena kesengajaan ataupun kelalaian.”

Atas tingginya jumlah dan beragamnya tindak pidana yang terjadi, hal ini memicu terjadinya perkembangan pelaku tindak pidana. Perkembangan pelaku tindak pidana yang dimaksud adalah dimana anak sebagai pelaku tindak pidana. Pergaulan seorang anak diluar lingkungan keluarga memiliki pengaruh yang besar dalam perubahan karakter anak yang awalnya telah terbentuk, sehingga peran orang tua dalam mendidik anak merupakan tugas yang sangat penting. Apabila peran orang tua dalam mendidik anak kurang maksimal, hal ini memicu anak untuk melakukan perbuatan menyimpang dan melawan hukum. Sebagaimana firman Allah SWT dalam QS. Al-Anfal ayat 28; Artinya :"Dan ketahuilah bahwa hartamu dan anak-anakmu itu hanyalah sebagai cobaan dan sesungguhnya di sisi Allah ada pahala yang besar.” 
Anak sebagai pelaku tindak pidana dalam Undang-Undang No. 11 Tahun 2012 tentang Sistem Peradilan Pidana Anak (SPPA) perubahan atas Undang-Undang No. 3 Tahun 1997 tentang Pengadilan Anak disebut anak yang berkonflik dengan hukum yang selanjutnya disebut Anak adalah anak yang telah berumur 12 (dua belas) tahun, tetapi belum berumur 18 (delapan belas) tahun yang diduga melakukan tindak pidana.

Menurut data dari Departemen Kehakiman dan Hak Asasi Manusia, secara nasional , Mei Tahun 2003, jumlah anak yang bermasalah dengan hukum berada di Lembaga Pemasyarakatan dan Rumah Tahanan Negara berjumlah 3004 anak. Penanganan kasus anak sebagai pelaku tindak pidana dengan jumlah dan bentuk yang beragam, mendorong Pemerintah memberikan perhatian khusus terhadap hal ini. Salah satunya yaitu penetapan Undang-Undang No. 3 Tahun 1997 tentang Pengadilan Anak yang saat ini berganti menjadi Undang-Undang No. 11 Tahun 2012 tentang Sistem Peradilan Pidana Anak. Upaya Pemerintah memberikan perhatian khusus dengan adanya ketentuan Undang-Undang No. 11 Tahun 2012 tentang Sistem Peradilan Pidana Anak merupakan upaya untuk tetap menegakkan keadilan dari tujuan hukum itu sendiri dengan anak sebagai pelaku tindak pidana. Sesuai dengan firman Allah SWT dalam QS. Al-Ma'idah ayat 48; Artinya : "Dan Kami telah menurunkan Kitab (Al-Qur'an) kepadamu (Muhammad) dengan membawa kebenaran, yang membenarkan kitab-kitab yang diturunkan sebelumnya dan menjaganya, maka putuskanlah perkara mereka menurut apa yang diturunkan Allah dan janganlah engkau mengikuti keinginan mereka dengan meninggalkn kebenaran yang telah datang kepadamu. Untuk setiap umat di antara kamu, Kami berikan aturan dan jalan yang terang. Kalau Allah menghendaki, niscaya kamu dijadikan-Nya satu umat (saja), tetapi Allah hendak menguji kamu terhadap karunia yang telah diberikan-Nya kepadamu, maka berlomba-lombalah berbuat kebajikan. Hanya kepada Allah kamu semua kembali, lalu diberitahukan-Nya kepadamu terhadap apa yang dahulu kamu perselisihkan."

Setiap anak pelaku tindak pidana yang masuk dalam sistem peradilan pidana harus diperlakukan secara manusiawi sebagaimana diatur dalam ketentuan Undang-undang No. 35 Tahun 2014 perubahan atas Undang-Undang No. 23 Tahun 2002 tentang Perlindungan Anak, yaitu nondiskriminasi, kepentingan terbaik bagi anak, hak untuk hidup, hidup dan perkembangannya, serta penghargaan terhadap pendapat anak.

Dengan adanya ketentuan-ketentuan mengenai anak sebagai pelaku tindak pidana, maka dalam Undang-Undang No. 11 Tahun 2012 tentang Sistem Peradilan Pidana Anak dikenal adanya upaya Diversi. Diversi merupakan pengalihan penyelesaian perkara anak dari proses peradilan 
pidana ke proses diluar peradilan pidana. Upaya diversi wajib dilakukan di tingkat Penyidikan, Penuntutan, dan Pemeriksaan perkara anak di Pengadilan Negeri. Pelaksanaan diversi ditiap tingkat pemeriksaan masih terkendala oleh karena konsep diversi merupakan konsep yang baru di Indonesia dan ditiap tingkat pemeriksaan tersebut belum memiliki ketentuan, tindakan apa yang tepat dalam pelaksanaan upaya diversi tersebut terhadap anak sebagai pelaku tindak pidana.

Pada ketentuan Pasal 8 ayat (1) Undang-Undang No. 11 Tahun 2012 tentang Sistem Peradilan Pidana Anak, Proses Diversi dilakukan melalui musyawarah dengan melibatkan Anak dan orang tua/Walinya, korban dan/atau orang tua/Walinya, Pembimbing Kemasyarakatan, dan Pekerja Sosial Profesional berdasarkan pendekatan Keadilan Restoratif. Pasal 1 ayat (6) UndangUndang No. 11 Tahun 2012 tentang Sistem Peradilan Pidana Anak, Keadilan Restoratif adalah penyelesaian perkara tindak pidana dengan melibatkan pelaku, korban, keluarga pelaku/korban, dan pihak lain yang terkait untuk bersama-sama mencari penyelesaian yang adil dengan menekankan pemulihan kembali pada keadaan semula, dan bukan pembalasan. Meskipun telah ditentukan pelaksanaan diversi dilakukan secara musyawarah berdasarkan pendekatan Keadilan Restoratif, hal ini tidak memberikan gambaran tindakan yang jelas kepada para penegak hukum disetiap proses pemeriksaan dan pihak-pihak yang terkait masih perlu bersama-sama mencari penyelesaian yang adil dengan menekankan pemulihan kembali pada keadaan semula, dan bukan pembalasan, sebagaimana tertuang dalam pasal 1 ayat (6) Undang-Undang No. 11 Tahun 2012 tentang Sistem Peradilan Pidana Anak. Sehingga perlu adanya tindakan tepat yang berdasar pada Keadilan Restoratif untuk penyelesaian tindak pidana yang dilakukan oleh anak. Salah satu tindakan menurut Penulis yang dapat diterapkan dalam pelaksanaan diversi yaitu musyawarah yang dilakukan dengan pendekatan Mediasi. Mediasi merupakan proses penyelesain sengketa dengan keterlibatan pihak ketiga sebagai pihak yang netral dan imparsial.

Mediasi adalah salah satu penyelesaian sengketa yang tertuang dalam ketentuan UndangUndang No. 30 Tahun 1999 tentang Arbitrase dan Alternatif Penyelesaian Sengketa, pada umumnya ketentuan ini merupakan penyelesaian sengketa dibidang keperdataan . Dalam ketentuan tersebut terdapat berbagai bentuk penyelesaian sengketa selain dari pada mediasi, antara lain konsultasi, negosiasi, konsiliasi, penyelesaian sengketa atau penilaian ahli. Menurut Penulis, mediasi dapat diterapkan dalam pelaksanaan diversi dikarenakan proses mediasi pada prinsipnya menyelesaikan masalah berdasarkan atas kesepakatan-kesepakatan para pihak sebagai hasil (kaputusan) akhir dari proses mediasi tersebut dan keterlibatan pihak ketiga sebagai pihak yang 
membantu dan mengupayakan proses pengambilan keputusan menjadi lebih baik dibandingkan dengan bentuk-bentuk alternatif lainnya. Meskipun mediasi merupakan salah satu alternatif penyelesaian sengketa dibidang keperdataan, namun pada prinsipnya mediasi memiliki karakteristik yang tepat diterapkan dalam proses penyelesaian tindak pidana yang dilakukan oleh anak untuk pelaksanaan diversi dalam Sistem Peradilan Pidana Anak.; (1) Apakah penerapan Alternatif untuk diversi dalam Sistem Peradilan Pidana Anak tidak bertentangan dengan ketentuan Undang-Undang No. 11 Tahun 2012 tentang Sistem Peradilan Pidana Anak?; (2) Tindakan atau cara apa yang dapat dilakukan ditingkat Penyidikan, Penuntutan, hingga di Pengadilan sebagai upaya diversi dalam Sistem Peradilan Pidana Anak?

\section{PEMBAHASAN}

\section{Penerapan Alternatif Penyelesaian Sengketa (APS) untuk Diversi dalam Sistem Peradilan Pidana Anak (SPPA)}

Alternatif Penyelesaian Sengketa (APS) atau dalam bahasa asing dikenal sebagai Alternative Dispute Resolution (ADR) ini merupakan penyelesaian sengketa diluar pengadilan dalam ruang lingkup keperdataan . Jenis-jenis Alternatif Penyelesaian Sengketa yang diatur dalam Undang-Undang No. 30 Tahun 1999 tentang Arbitrase dan Alternatif Penyelesaian Sengketa antara lain Konsultasi, Negosiasi, Mediasi, Konsiliasi, atau Penilaian Ahli.

Walaupun alternatif penyelesaian sengketa ini merupakan penyelesaian sengketa diluar pengadilan dalam ruang lingkup keperdataan, tetapi penerapannya dalam implementasi penegakan hukum seringkali dan terkadang salah satu dari beberapa jenis Alternatif Penyelesaian Sengketa tersebut digunakan pula dalam ruang lingkup pidana untuk penyelesaian perkara pidana. Sebagai contoh jenis Alternatif Penyelesaian Sengketa yang terkadang digunakan untuk penyelesaian perkara pidana yaitu Mediasi. Penyelesaian perkara pidana dengan menggunakan metode pendekatan mediasi ini dianggap sesuai dan tidak bertentangan.

Dalam implementasi penegakan hukumnya mediasi dapat diterapkan untuk Diversi dalam Sistem Peradilan Pidana Anak. Diversi merupakan pengalihan penyelesaian perkara anak dari proses peradilan pidana ke proses diluar peradilan pidana. Pelaksanaan upaya diversi wajib disetiap tingkat pemeriksaan dan dilakukan dengan cara musyawarah dengan melibatkan Anak dan orang tua/walinya, korban dan/atau orang tua/walinya, Pembimbing Kemasyarakatan, dan Pekerja Sosial Profesional berdasarkan Keadilan Restoratif . 
Dari hasil wawancara langsung kepada Kanit VI - PPA Polrestabes Makassar, Jaksa Penuntut Umum (Kejaksaan Negeri Makassar), dan Hakim Anak (Pengadilan Negeri Makassar) Penulis memperoleh gambaran upaya diversi ditiap tingkat pemeriksaan dilakukan dengan menggunakan metode pendekatan mediasi. Dimana penyidik, jaksa penuntut umum, dan hakim berperan sebagai mediator dan fasilitator. Pelaksanaan diversi tersebut dari hasil penelitian oleh Penulis ditiap tingkat pemeriksaan berlangsung secara musyawarah yang dihadiri oleh pihak pelaku Anak, pihak Korban, Pembimbing Kemasyarakatan dan Balai Pemasyarakatan. Dalam pelaksanaannya yang dilakukan secara musyawarah dengan menggunakan metode pendekatan mediasi terjadi negosiasi antara kedua belah pihak. Negosiasi bertujuan untuk mencapai kesepakatan bersama antara kedua pihak dengan memperhatikan kepentingan pihak pelaku anak dan pihak korban. Negosiasi yang seringkali terjadi antara pihak pelaku anak dan pihak korban yaitu mengenai besaran ganti rugi, dan pencabutan laporan oleh korban terhadap pelaku anak.

Penerapan mediasi dan terjadinya negosiasi ini untuk upaya diversi dalam Sistem Peradilan Pidana Anak dianggap tidak bertentangan dan telah sesuai dengan apa yang diamanahkan dalam ketentuan Undang-Undang No. 11 Tahun 2012 tentang Sistem Peradilan Pidana Anak. Hal ini dikarenakan pelakunya adalah anak, anak dianggap belum cakap (belum mampu berpikir baik dan buruknya tindakan yang dilakukan), maka dari itu anak memperoleh keistimewaan untuk hal ini atas tindak pidana yang dilakukan.

Tindakan / Cara yang dilakukan ditingkat Penyidikan, Penuntutan, hingga di Pengadilan sebagai upaya Diversi dalam Sistem Peradilan Pidana Anak

Berlandaskan pada Pasal 7 ayat (1) Undang-Undang No. 11 Tahun 2012 tentang Sistem Peradilan Pidana Anak, bahwa pada tingkat penyidikan, penuntutan, dan pemeriksaan perkara Anak di pengadilan negeri wajib diupayakan Diversi . Atas dasar ketentuan tersebut Penulis melakukan penelitian dibeberapa lokasi penelitian, dengan hasil ditiap tingkat pemeriksaan sebagai berikut : (1) Tingkat Penyidikan : Ditingkat penyidikan, Penulis melakukan penelitian di Polrestabes Makassar dengan melakukan wawancara langsung kepada IPTU Ismail, SH (Kanit VI - PPA / Perlindungan Perempuan dan Anak).

Ditingkat penyidikan yang dilakukan oleh penyidik dari Unit VI - PPA (Perlindungan Perempuan dan Anak) Polrestabes Makassar telah beberapa kali melakukan upaya diversi dimana anak sebagai pelaku tindak pidana. Upaya diversi yang telah dilakukan beberapa kali tersebut ada yang berhasil dan ada pula yang tidak berhasil. Upaya diversi yang berhasil dilakukan yaitu dalam 
penanganan kasus penganiayaan yang dilakukan oleh Anak berstatus sebagai pelajar ditingkat sekolah menengah pertama di Makassar. Kasus tersebut terjadi saling lapor antar kedua pihak.

Dalam penanganan kasus penganiayaan tersebut diupayakan diversi. Upaya diversi yang dilakukan berlangsung secara Musyawarah, dihadiri oleh kedua pihak yang saling lapor dan pihak Penyidik Unit VI - PPA Polrestabes Makassar. Musyawarah yang terjadi dapat dikatakan menggunakan metode pendekatan mediasi, karena prosesnya yang berlangsung layaknya mediasi. Berlangsungnya upaya diversi tersebut yang dilakukan menggunakan metode pendekatan mediasi terjadi negosiasi antar kedua pihak, negosiasi yang terjadi yaitu kedua pihak bersepakat untuk saling cabut laporan. Tercapainya negosiasi tersebut terjadi tanpa adanya tekanan dari pihak manapun dan murni memprioritaskan kepentingan Anak yang masih berstatus sebagai pelajar ditingkat sekolah menengah pertama. Sehingga, berlandaskan pada kesepakatan bersama tersebut proses penyidikan dihentikan dan upaya diversi yang dilakukan dalam penanganan kasus penganiayaan yang dilakukan oleh Anak berstatus sebagai pelajar ditingkat sekolah menengah pertama di Makassar dinyatakan berhasil; (2) Tingkat Penuntutan : Pada tingkat penuntutan ini, Penulis melakukan penelitian di Kejaksaan Negeri Makassar. Proses penelitian yang dilakukan oleh Penulis sama halnya ditingkat penyidikan yaitu melakukan wawancara langsung kepada Jaksa Rustiani Muin, SH yang pernah menangani kasus dan dalam penanganannya diupayakan Diversi.

Jaksa Rustiani Muin, SH telah beberapa kali melakukan upaya diversi dimana anak sebagai pelaku tindak pidana. Kurang lebih 3 kali upaya diversi yang telah dilakukan oleh Jaksa tersebut, dalam penanganan kasus pengroyokan dan pencurian yang dilakukan oleh Anak. Tetapi, upaya diversi yang dilakukan dalam penanganan kasus tersebut tidak ada yang berhasil. Ketidak berhasilan upaya diversi ditingkat penuntutan yang ditangani oleh Jaksa Rustiani Muin, SH terjadi karena faktor pertimbangan kasus yang dihadapi.

Meskipun upaya diversi tidak berhasil, Jaksa Rustiani Muin, SH memberikan penjelasan terhadap proses diversi yang dilakukan ditingkat penuntutan ini. Proses diversi yang dijelaskan oleh Jaksa tersebut yaitu dalam penanganannya terhadap kasus pencurian. Proses diversi yang dilakukan dihadiri oleh pihak korban, pihak pelaku anak, pembimbing kemasyarakatan, dan Penuntut dari Kejaksaan Negeri Makassar yaitu Jaksa Rustiani Muin, SH. Proses diversi yang terjadi berlangsung secara musyawarah, layaknya mediasi dan yang berperan sebagai mediator adalah Jaksa yang bersangkutan. Dalam mediasi yang dikatakan sebagai upaya diversi tersebut terjadi negosiasi, negosiasi yang terjadi yaitu besaran ganti kerugian yang diminta oleh pihak 
korban kepada pihak pelaku anak. Meskipun tercapainya kesepakatan negosiasi yang terjadi antara pihak korban dan pihak pelaku anak, kasus pencurian ini tetap dilanjutkan ke proses selanjutnya sesuai dengan ketentuan perundang-undangan. Alternatif Penyelesaian Sengketa merupakan suatu mekanisme penyelesaian sengketa yang dipahami sebagai alternatif atau opsi lain bagi para pihak yang bersengketa untuk menyelesaikan perkaranya selain melalui jalur pengadilan. Dalam Bahasa asing Alternatif Penyelesaian Sengketa dikenal sebagai ADR singkatan dari Alternative Dispute Resolution.

Beda halnya dalam Kamus Hukum, dalam Kamus Hukum memberikan masing-masing arti untuk Alternatif Penyelesaian Sengketa dan Alternative Dispute Resolution (ADR). Alternatif Penyelesaian Sengketa adalah lembaga penyelesaian sengketa atau beda pendapat melalui prosedur yang disepakati para pihak, yakni penyelesaian di luar pengadilan dengan cara konsultasi, negosiasi, mediasi, konsiliasi, atau penilaian ahli. Sedangkan untuk Alternative Dispute Resolution (ADR) adalah sebuah konsep yang mencakup berbagai bentuk penyelesaian sengketa selain dari proses peradilan melalui cara-cara yang sah menurut hukum, baik berdasarkan pendekatan konsensus atau tidak berdasarkan pendekatan konsensus. Alternatif Penyelesaian Sengketa merupakan penyelesaian sengketa diluar pengadilan untuk sengketa dibidang keperdataan.

Secara teori Alternatif Penyelesaian Sengketa dapat memberikan prosedur yang lebih murah, cepat, tidak kompleks seperti litigasi (melalui jalur pengadilan) formal. Penggunaan Alternatif Penyelesaian Sengketa tidak hanya ditujukan untuk mengatasi hambatan finansial terhadap pengadilan, namun menghadapi juga permasalahan yang mengandung faktor budaya, geografi, dan psikologi.

\section{Jenis-jenis Alternatif Penyelesaian Sengketa (APS)}

Secara umum penyelesaian sengketa dibidang keperdataan, baik nasional maupun internasional dapat dilakukan melalui berbagai cara, antara lain; (1) Negosiasi : Menurut Kamus Hukum, negosiasi merupakan proses tawar menawar dengan jalan berunding antara para pihak yang bersengketa untuk mencapai kesepakatan bersama. Sedangkan menurut para ahli yaitu Roger Fisher dan William Ury, negosiasi adalah komunikasi dua arah yang dirancang untuk mencapai kesepakatan pada saat kedua belah pihak memiliki berbagai kepentingan yang sama maupun yang berbeda. Negosiasi merupakan cara penyelesaian sengketa yang paling sederhana dan murah. Negosiasi merupakan sarana bagi pihak-pihak yang mengalami sengketa untuk mendiskusikan 
penyelesaiannya tanpa keterlibatan pihak ketiga atau penengah yang tidak berwenang mengambil keputusan. Karena pihak-pihak yang bersengketa adalah pihak yang paling tahu mengenai masalah yang menjadi sengketa dan bagaimana cara penyelesaian sengketa yang diinginkan. Dengan demikian, pihak yang bersengketa dapat mengontrol jalannya proses penyelesaian sengketa ke arah penyelesaian sengketa yang diharapkan. Namun, ada kalanya negosiasi mengalami kegagalan dan jalan buntu. Dalam keadaan demikian biasanya pihak yang bersengketa akan memilih penyelesaian sengketa melalui alternatif yang lain; (2) Mediasi : Menurut Kamus Hukum, mediasi merupakan pengikutsertaan pihak ketiga dalam penyelesaian sengketa antara dua pihak. Sedangkan pada umumnya, mediasi adalah negosiasi yang melibatkan pihak ketiga yang memiliki keahlian mengenai prosedur mediasi yang efektif, yang dapat membantu pihak-pihak yang bersengketa. Penyelesaian sengketa melalui mediasi adalah penyelesaian sengketa yang dilakukan oleh seorang yang benar-benar dipercaya kemampuannya untuk mempertemukan kepentingan pihak-pihak yang bersengketa yang disebut sebagai mediator. Mediator dalam mediasi berbeda halnya dengan hakim atau arbiter. Mediator tidak mempunyai kekuasaan untuk memaksakan suatu penyelesaian pada pihak-pihak yang bersengketa. Mediator membimbing para pihak untuk melakukan negosiasi sampai mendapat kesepakatan yang mengikat para pihak. Dalam mediasi tidak ada pihak yang menang atau kalah. Masing-masing pihak sama-sama menang, karena kesepakatan akhir yang diambil adalah hasil dari kemauan para pihak itu sendiri. Kemampuan seorang mediator sangat menentukan keberhasilan proses mediasi, tidak saja berupa pemahaman dan penguasaan terhadap konsep dan teknik mediasi, tetapi juga mengenai substansi masalah yang menjadi objek sengketa. Mediasi dapat berhasil baik jika para pihak berkeinginan untuk menyelesaikan persoalan tanpa niat permusuhan secara lama dan mendalam, maka mediasi adalah pilihan yang tepat; (3) Konsiliasi : Menurut Kamus Hukum, konsiliasi merupakan suatu usaha mempertemukan keinginan para pihak yang bersengketa untuk mencapai kesepakatan guna menyelesaikan sengketa secara kekeluargaan. Secara umum konsiliasi dikatakan sebagai lanjutan dari mediasi. Dimana mediator beralih fungsi menjadi konsiliator. Dalam hal ini, konsiliator memiliki wewenang untuk menyusun dan merumuskan penyelesaian untuk ditawarkan kepada para pihak. Jika para pihak menyetujui dan menyepakati, solusi yang dibuat oleh konsiliator bersifat final dan mengikat. Penggunaan konsiliator (pihak ketiga) secara aktif maupun tidak aktif duduk diantara pihak-pihak yang bersengketa bertujuan untuk membantu mereka memutuskan suatu persetujuan. Selain itu, konsiliasi melibatkan intervensi pihak ketiga yang lebih dalam (lebih 
memaksa) dan aktif, yang mengasumsikan kecenderungan terhadap norma tertentu dan memiliki orientasi edukatif bagi satu atau lebih pihak terkait.

\section{Faktor-faktor Penggunaan Alternatif Penyelesaian Sengketa (APS)}

Berdasarkan atas pengertian Alternatif Penyelesaian Sengketa itu sendiri, maka terdapat beberapa faktor mengapa Alternatif Penyelesaian Sengketa digunakan yang bersumber dari kritikan terhadap lembaga pengadilan, yaitu; (1) Waktu : Proses persidangan yang berlarut-larut atau terlalu lama dan kesulitan mendapatkan suatu putusan yang benar-benar final dan mengikat, sebab para pihak memiliki hak untuk melakukan upaya hukum yang lainnya (banding, kasasi, dan peninjauan kembali). Sehingga waktu yang tidak bisa dikontrol oleh para pihak; (2) Adversary : Proses beracara dalam pengadilan memaksa para pihak untuk saling menyerang; (3) Biaya Mahal : Biaya pengadilan dibeberapa negara dianggap mahal (khususnya bagi masyarakat pedalaman, hal ini akan ditambah dengan biaya transportasi). Ditambah lagi dengan sistem peradilan yang mempunyai prosedur yang bertingkat-tingkat, belum lagi biaya-biaya informal dalam sistem peradilan. Semakin lama penyelesaian suatu perkara, maka akan semakin besar baiay yang akan dikeluarkan. Orang yang berperkara dalam pengadilan harus mengerahkan segala sumber daya, waktu, dan pikiran; (4) Prosedur yang Ketat : Dengan adanya prosedur beracara yang ketat, yang terkadang menghilangkan keleluasaan para pihak untuk mencari inovasi alternatif-alternatif penyelesaian. Sering kali kepentingan yang sebenarnya dari para pihak yang bersengketa tidak tercermin dalam gugatan/tuntutan yang diajukan; (5) Lawyer Oriented : Karena sistem prosedur yang kompleks dalam peradilan, maka hanya pihak yang mempunyai keahlian saja yang dapat beracara di pengadilan. Oleh karena itu, pihak yang bersengketa banyak yang memberi wewenang kepada pengacaranya (kuasa hukum), dimana terkadang pengacara (kuasa hukum) tidak mengerti benar kepentingan dari si klien; (6) Ungkapan mengenai Citra Pengadilan : Berbagai ungkapan yang ditujukan ke arah proses penyelesaian sengketa melalui litigasi semakin menyudutkan popularitas peradilan. Ada ungkapan yang bersumber dari pepatah, ada pula yang bersumber dari kesan yang ditampung dari kenyataan praktik sehari-hari.

Contoh dari beberapa ungkapan pepatah, mengatakan : (a) Pepatah Cina menyatakan :“A lawsuit breeds ten years of hatered".Yang berarti "Berperkara di pengadilan akan menimbulkan kebencian berpuluh-puluh tahun.”; (b) Pepatah Cina yang lain menyatakan :"Going to the law is losing a cow for the sake of cat". Yang berarti "Seseorang yang berperkara akan kehilangan lembu, hanya untuk mendapatkan seekor kucing"; (c) Jack Etthridge mengungkapkan :"Litigation 
paralyze people. It makes them enemies. It pets them not only against one another but against the other's employed combatant". Yang berarti “Berperkara membuat orang lumpuh, karena membuat para pihak bermusuhan, tidak hanya para pihak, tetapi melibatkan semua pihak yang terkait).; (7) Win-Lose Situation : Sistem peradilan didasarkan pada nilai benar atau salah, yang pada akhirnya akan menghasilkan situasi yang kalah atau menang; (8) Kurangnya Kemampuan Hakim : Sejalan dengan era global dan perkembangan teknologi, diharapkan seorang Hakim adalah seseorang yang mempunyai sumber daya dan pengetahuan yang lebih. Mereka dituntut untuk banyak belajar. Namun kenyataannya, Hakim hanya mengetahui suatu hal secara terbatas dan tidak didukung oleh keahlian yang profesional. Oleh karena itu, sulit untuk mengharapkan suatu penyelesaian sengketa yang kompleks, secara baik, dan objektif dari para Hakim sebab kualitas Hakim tidak seimbang dengan perkembangan teknologi dan menyebabkan putusan Hakim sering menyimpang dari permasalahan pokoknya; (9) Hubungan Putus : Dengan adanya sistem win-lose, maka untuk kasus perdata atau bisnis, maka hubungan para pihak menjadi putus atau tidak harmonis lagi; (10) Memicu Konflik Baru : Karena untuk menyelamatkan muka dan telah terputusnya hubungan, maka hal tersebut dapat memicu konflik yang baru lagi.

Pengertian Diversi Dalam Naskah Akademik Rancangan Undang-Undang (RUU) Sistem Peradilan Pidana Anak, Diversi adalah suatu pengalihan penyelesaian kasus-kasus anak yang diduga melakukan tindak pidana tertentu dari proses pidana formal ke penyelesaian damai antara tersangka/terdakwa/pelaku tindak pidana dengan korban yang difasilitasi oleh keluarga dan/atau masyarakat, Pembimbing Kemasyarakatan Anak, Polisi, Jaksa atau Hakim. Lain halnya dalam Pasal 1 ayat (7) Undang-Undang No. 11 Tahun 2012 tentang Sistem Peradilan Pidana Anak, diversi adalah pengalihan penyelesaian perkara Anak dari proses peradilan pidana ke proses di luar peradilan pidana. Diversi merupakan kebijakan yang dilakukan untuk menghindarkan pelaku dari sistem peradilan pidana yang formal dan memberikan perlindungan dan rehabilitasi (protection and rehabilitation) kepada pelaku sebagai upaya untuk mencegah anak menjadi pelaku kriminal dewasa

\section{Pengertian Sistem Peradilan Pidana Anak (SPPA)}

Istilah Sistem Peradilan Pidana Anak (SPPA) merupakan terjemahan dari istilah The Juvenile Justice System, yaitu istilah yang digunakan sedefinisi dengan sejumlah institusi yang tergabung dalam pengadilan, yang meliputi polisi, jaksa penuntut umum dan penasihat hukum, lembaga pengawasan, pusat-pusat penahanan anak,dan fasilitas-fasilitas pembinaan anak. 
Didalam kata Sistem Peradilan Pidana Anak, terdapat istilah "sistem peradilan pidana" dan istilah "anak". Kata "anak" dalam frasa "sistem peradilan pidana anak" mesti dicantumkan, karena untuk membedakan dengan sistem peradilan pidana dewasa. Apabila mengacu pada ketentuan yang terdahulu yaitu Undang-Undang No. 3 Tahun 1997 tentang Pengadilan Anak, maka yang dimaksud dengan anak adalah anak nakal, yakni anak yang melakukan tindak pidana, ataupun anak yang melakukan perbuatan terlarang bagi anak. Definisi tersebut mengandung permasalahan secara teoretis yakni menggabungkan tindak pidana dengan perbuatan yang dilarang, sehingga mengakibatkan penafsiran yang tidak tunggal. Permasalahan definisi tersebut jelas bermasalah, sehingga diperbaiki dalam Undang-Undang No. 11 Tahun 2012 tentang Sistem Peradilan Pidana Anak, bahwa yang dimaksud dengan anak dalam Sistem Peradilan Pidana Anak adalah anak yang berkonflik dengan hukum. Sehingga dalam ketentuan Undang-Undang No. 11 Tahun 2012 tentang Sistem Peradilan Pidana Anak yang dimaksud dengan Sistem Peradilan Pidana Anak adalah keseluruhan proses penyelesaian perkara Anak yang berhadapan dengan hukum, mulai tahap penyelidikan sampai dengan tahap pembimbingan setelah menjalani pidana.

\section{SIMPULAN}

Penerapan Alternatif Penyelesaian Sengketa (APS) atau dalam bahasa asing dikenal sebagai Alternative Dispute Resolution (ADR) yaitu mediasi untuk diversi dalam Sistem Peradilan Pidana Anak (SPPA) tidak bertentangan dan telah sesuai dengan apa yang diamanahkan dalam ketentuan Undang-Undang No. 11 Tahun 2012 tentang Sistem Peradilan Pidana Anak. Walaupun Alternatif Penyelesaian Sengketa yang diterapkan dikenal untuk ruang lingkup keperdataan, namun dalam implementasi penegakan hukum yang terjadi hal tersebut terkadang dan sering pula digunakan dalam penyelesaian perkara dalam ruang lingkup pidana.

Berdasarkan hasil penelitian Penulis yang dilakukan dibeberapa lokasi penelitian, tindakan dan cara yang dilakukan disetiap tingkat pemeriksaan untuk upaya diversi dilakukan secara musyawarah yang dihadiri oleh pihak-pihak terkait. Musyawarah yang berlangsung dilaksanakan dengan menggunakan metode pendekatan mediasi, dan dalam prosesnya terjadi negosiasi yang disepakati bersama sebagai indikator keberhasilan upaya diversi yang dilakukan. 


\section{DAFTAR PUSTAKA}

Abbas, Syahrizal. 2009. Mediasi dalam Perspektif Hukum Syariah, Hukum Adat, dan Hukum Nasional. Jakarta : Kencana.

Anonim. 2008. Kamus Hukum. Bandung : Citra Umbara.

Amriani, Nurnaningsih. 2011. Mediasi - Alternatif Penyelesaian Sengketa Perdata di Pengadilan. Jakarta : Rajawali Pers.

Djamil, M. Nasir. 2013. Anak Bukan untuk Dihukum. Jakarta : Sinar Grafika.

Karjadi, M dan Soesilo, R. 1997. Kitab Undang-Undang Hukum Acara Pidana dengan Penjelasan Resmi dan Komentar. Bogor : Politeia.

Marlina. 2012. Peradilan Pidana Anak di Indonesia Pengembangan Konsep Diversi dan Restorative Justice. Bandung : Refika Aditama.

Nashriana. 2012. Perlindungan Hukum Pidana bagi Anak di Indonesia. Jakarta : Rajawali Pers.

Soekanto, Soerjono. 1986. Pengantar Penelitian Hukum. Jakarta : UI Press.

. 1989. Suatu Sosiologi Hukum terhadap Masalah Sosial. Bandung : Citra Aditya Bakti.

Soesilo, R. 1996. Kitab Undang-Undang Hukum Pidana (KUHP) sera Komentar-Komentarnya Lengkap Pasal Demi Pasal. Bogor : Politeia.

Sunggono, Bambang. 2013. Metodologi Penelitian Hukum. Jakarta : Rajawali Pers.

Syahrani, H. Riduan. 2013. Rangkuman Intisari Ilmu Hukum. Bandung : Citra Aditya Bakti.

Widiyati, Ninik dan Warsita, Yulius. 1987. Kejahatan dalam Masyarakat dan Pencegahannya. Jakarta : Bina Aksara. 